\title{
Diversity of Pathogenic Candida Species Colonizing Women with and without Candida Vaginitis in Dar es Salaam Region, Tanzania
}

\author{
Lucy Andrew Namkinga \\ Department of Molecular Biology and Biotechnology (MBB) \\ P.O.Box 35179, University of Dar es Salaam, Tanzania \\ Tel: 255-222-410-223 E-mail: odulajalucy@yahoo.com
}

Received: October 27, 2012 Accepted: November 10, 2012

doi:10.5296/jbls.v4i1.2835 URL: http://dx.doi.org/10.5296/jbls.v4i1.2835

\begin{abstract}
The aim of this study was to establish phenotypic and genetic diversities of Candida species isolated from women with recurrent Candida vaginitis. A total of 3000 samples were cultured from 3000 women with and without complaints of vaginal discharges and pruritis vulvae. Growth characteristics on Sabouraud's dextrose agar and on conidia enhancing media (Corn meal agar) resulted in isolation of 5440 distinct colonies of Candida species. They were then analyzed by germ tube test to separate $C$. albicans from non-albicans Candida species. For confirmation, 300 doubtful isolates were then tested on API 20C AUX and by polymerase chain reaction.
\end{abstract}

The results showed Candida albicans species to be dominant 3661 (67.29\%) while non-albicans Candida species presented only 1779 (32.71\%) which included C. glabrata 435(8.0\%), C. tropicalis 762(14.0\%), C. krusei 163(3.0\%), C. famata 109(2.0\%), C. parapsilosis 131(2.41\%), C. guilliermondii and C. lusitaniae each 27(0.5\%) respectively, $C$. incospicua 13 (0.24\%), C. norvegensis 82(1.5\%), C. colliculosa $16(0.3 \%)$ and C. magnoliae $15(0.27 \%)$. On genotypic diversity, the principle coordinate analysis of the PCR results for the genetic relatedness and genetic distances revealed the distribution of 200 isolates tested as: $C$. albicans 90(36\%), C. glabrata 40(20\%), C. krusei 20 (10\%), C. tropicalis 20 (10\%), C. famata 10(5\%), C. parapsilosis 5(2.5\%), C. norvegensis 6(3\%), C. lusitaniae 4(2\%), and C. guilliermondii $5(2.5 \%)$.

From this study it shows that a combination of biochemical methods and PCR technology may identify most of the isolates, including the germ tube negative isolates. Both symptomatic and asymptomatic women possessed similar species and genotypic diversities. However, in symptomatic women, a single host can be colonized with multiple species or multiple 
genotypes of the same species. In order to establish if the same species behave differently in symptomatic and asymptomatic individuals, this study recommend further investigation on virulent factors.

Keywords: Diversity, Pathogen, Candida, Vaginits, Pruritis

\section{Introduction}

The genus Candida has diverse species that are common residents of soil and of the mucosal surfaces of human gastrointestinal tract, genito-urinary tract and the mouth, and are capable of causing oral thrush or vaginal thrush. The most common vaginal isolate include $C$. albicans with a prevalence of $70-90 \%$ and less frequently non-albicans Candida species such as $C$. tropicalis, C. glabrata (Torulopsis glabrata), C. kefyr (C. pseudotropicalis), C. krusei, C. famata, C. parapsilosis, and C. lusitaniae (Xu et al., 1999; Abu-Elteen, 2001; Chong et al., 2003; Namkinga et al., 2005). These different Candida species have been associated with differences in the morphotype and virulence factors such as germ tube and mycelia formation, proteinase secretion, the changes in vaginal $\mathrm{pH}$, phenotypic switching and ability to cause vaginal candidiasis (Sobel et al., 1981; Sobel, 1985; Hunter et al., 1989; Cutler, 1991; De Bernardis, et al., 1993; Cassone et al., 1995; Hube, 1996; Samaranayake et al., 2003; Namkinga et al., 2005). However, a significant increase in non-albicans Candida species and formation of virulence factors have been reported to be associated with recurrent Candida vaginitis (Sobel, 1992; Sobel, 1998; Chong, et al., 2003; Namkinga, et al., 2005).

The incidence of Candida infections has dramatically increased in recent years as a result of a large increase in HIV/AIDS cases, thus an ever-expanding population with immuno-compromise due to mucosal or cutaneous barrier disruption, defects in the number and function of neutrophils or in cell-mediated immunity, metabolic dysfunction, organ transplantation and extremes of age ( $<1$ year and $>70$ years). The expanded use of immunosuppressive chemotherapies, and transplantation further increases the risk for both common and uncommon Candida species. In addition, as our aging population becomes increasingly mobile, environmental exposures to a variety of endemic fungal pathogens become more common and sometimes, may further increase the risk of fungal diseases (Xu et al., 1999; Samaranayake et al., 2003; Pfaller and Diekema, 2004; Walsh et al., 2004; Nucci, and Marr, 2005; Chu et al., 2006; Pfaller and Diekema, 2007). Other factors that have been associated with VC include: extensive use of broad spectrum antibiotics (Nasibwa et al., 1994), oral contraceptives (Baeten et al., 2001) and to a lesser extent corticosteroids and other immunosuppressive drugs (Baeten et al., 2001). Also pregnancy and uncontrolled diabetes (Sobel, 1992; de Leon et al., 2002), promiscuity (Foxman, 1992; Ginter et al., 1992; Spinillo et al., 1993; Marin et al., 2000), poor hygiene (Marin et al., 2000), iron deficiency anaemia (Higgs and Wells, 1972) and allergies from condom usage (Eckert et al., 1998). The prevalence of VC is low in pre-pubertal girls (Fischer, 2001) and in post-menopausal women (Barhan and Ezenagu, 1997), emphasizing the influence of hormones through Ph changes (Dennerstein, 1998; Baeten et al., 2001). VC in postmenopausal women has been associated with hormonal replacement therapy, uncontrolled diabetes, and immunosuppression caused by medication or disease (Nwokolo and Boag, 2000). 
Despite all the above-mentioned putative and precipitating factors, there are, however, cases of VC without a recognizable predisposing factor (Sobel, 1985). In these women, the exact mechanism of pathogenesis is unclear. It has been postulated that allergy (Moraes, 1998), certain blood groups (Chaim et al., 1997), use of commercially available solutions for vulvo-perineal cleaning or vaginal douching (Spinillo et al., 1993) could be the cause for the occurrence of VC in such women. Although C. albicans is the most frequent species isolated, other species such as C. tropicalis, C. guilliermondii, C. krusei, C. parapsilosis and C. glabrata have increasingly been recognized as pathogens with a wide distribution (Hazen, 1995, Fidel et $a l ., 1999)$. The significant increase in the frequency of candidiasis has promoted the study and development of a variety of molecular based techniques aiming at the replacement of the traditional methods used for the identification and typing of Candida clinical isolates.

The purpose of this investigation was to identify and characterize the diverse species of Candida from women with a history of symptomatic vaginal candidiasis in HIV infected individuals, pregnant women and in symptomless healthy carriers of Candida, by using biochemical and molecular methods. To the best knowledge of this study, this is the first study in Tanzania, which comprehensively characterized a large number of vaginal Candida species over an extended period of time (2006-2010), using multiple methods.

\section{Materials and Methods}

A total of 3000 high vaginal swabs were collected from women with and without symptoms of vaginal Candidiasis who visited HIV and gynecological clinics from Private and Government hospitals of Dar Es Salaam Region, Tanzania. The inclusion criterion of patients in this study was women from different races and a wide age range (13-50 years) with complaints of vaginal discharges and/or pruritis vulvae also health carriers of Candida were included. Women with vaginal discharge (thick cudy white-yellowish), vulva erythema, burning and severe vulva itching were considered to have vaginal candidiasis (VC) (Denning, 1995, Namkinga et al., 2005).

All specimens were processed in the Department of Molecular biology and biotechnology, University of Dar Es Salaam, Tanzania. Specimens from transport media were immediately cultured on Sabouraud's dextrose agar (Oxoid, Hampshire. UK). The wet mounts (from specimens) were prepared and examined microscopically by an experienced technician for the presence of yeast cells and trichomonas vaginalis. Gram stained smears were also prepared. Provisional detection of Candida species was based on colonial morphology on Sabouraud dextrose agar (SDA) media containing $0.005 \%$ chloramphenicol and $0.05 \%$ cycloheximide. Women were told to come after two weeks for their results. Symptomatic treatments were given to all women with $\mathrm{VC}$ and were told to come after seven days of treatment for evaluation. Indicated treatments were anti-fungal vaginal pesarries/ creams commonly found in Tanzania markets (clotrimazole, miconazole ketoconazole, nystatin), and anti-fungal oral tablets (ketoconazole, fluconazole, itraconazole) and for the individuals where the doctor feels that they have mixed infections, antibiotics were indicated. During the second visit, the subjects were interviewed again and high vaginal swabs taken for laboratory analysis. For those with the disappearance of symptoms or discomforts were told to come for check-up on monthly 


\section{MInstitute Macrothink $_{\text {Intion }}$}

basis for three months consecutively. For cases where symptoms persist or reoccur for three months consecutively despite of treatment with different anti-fungal agents were considered as recurrent cases. Recurrent cases were maintained again for three more months to find out the reasons for their recurrence in each visit.

Morphologically distinct yeast colonies from each culture were transferred and stored on Sabouraud's Dextrose agar slants for species identification and subsequent DNA fingerprinting. Yeast species were identified by growth on SDA to characterize the yeasts forms, and on conidia enhancing media; Corn meal agar (Oxoid, Hampshire. UK) inorder to characterize the mycelia forms. Germ tube test performed on horse serum (Oxoid, Hampshire. England) was used to separate Candida albicans from non-albicans Candida species. Biochemical testing with the Analytical Profile Index (API 20C) Candida (BioMerieux- SA, France) was used to speciate Candida based on sugar fermentation/assimilation. A few randomly selected isolates and the doubtful ones (total $n=540$ ), were further subjected to identification by API 20C AUX kits (BioMerieux- SA, France). Out of these 540 isolates, some few more $(n=200)$ isolates were identified by RAPD fingerprinting. Stock cultures of Candida albicans (ATCC 32354), C. glabrata (ATCC 2001), C. albicans (HG 392), C. guilliermondii (ATCC 6260), were provided from Nijmegen University, Netherlands and were used as control.

DNA was amplified on a Techne-Thermocycler (Techne-Genius model FGENO2TD, Germany) according to the conditions described by Liu et al (1996). Thermocycling was achieved according to the following program: Initial denaturation at $94^{\circ} \mathrm{C}$ for 3 minutes followed by 45 cycles of: $1 \mathrm{~min}$ at $95^{\circ} \mathrm{C}$ denaturation, $1 \mathrm{~min}$ at $35^{\circ} \mathrm{C}$ annealing and $2 \mathrm{~min}$ at $72^{\circ} \mathrm{C}$ elongation. The reaction ended with a 10 min extension at $72^{\circ} \mathrm{C}$. The reaction mix contained $2 \mu 110 \mathrm{X}$ reaction buffer [16 $\mathrm{mM}\left(\mathrm{NH}_{4}\right)_{2} \mathrm{SO}_{4}, 70 \mathrm{mM}$ Tris-HCI pH (8.8), 0.1\% Tween 20]; $2 \mu \mathrm{dNTP}$ ( $2 \mathrm{mM}) ; 0.20 \mu \mathrm{l}$ of Taq DNA polymerase; $2 \mu \mathrm{l} \mathrm{MgC12}(25 \mathrm{mM}), 1 \mu \mathrm{l}$ primer $(1.0 \mu \mathrm{g} \mathrm{ml}-1)$ [For primers used, see Table 3.3] and $1 \mu \mathrm{l}$ template DNA (ca. 10-20 ng). Each reaction was carried out in triplicate. Twentyfive nanograms of each of the Candida albicans (ATCC 32354), Candida glabrata (ATCC 2001), Candida albicans (HG 392) and Candida guilliermondii (ATCC 6260) were used as a positive control for each sample run.

A total of 11 primers (Table 1), were tested in the assay. The presence and absence of each RAPD band was analyzed by visual inspection of gel photographs (Figure 1).

Table 1. List of 10-mer primers (Operon Technologies Inc. Alameda Canada) used in this study

\begin{tabular}{|l|l|l|}
\hline Sn & Primer & Sequence \\
\hline 1 & OPB-01 & 5'-GTTTCGCTCC-3' \\
\hline 2 & OPA-08 & 5'-GTGACGTAGG-3' \\
\hline 3 & OPU-15 & 5'-ACGGGCCAGT-3' \\
\hline 4 & OPB-07 & 5'-GGTGACGCAG-3' \\
\hline 5 & OPAX-20 & 5'-GGTCCCTGAC-3' \\
\hline 6 & OPC-16 & 5'-CACACTCCAG-3' \\
\hline 7 & OPAW 15 & 5'-CCAGTCCCAA-3' \\
\hline 8 & OPAW-08 & 5'-CTGTCTGTGG-3' \\
\hline 9 & OPB-10 & 5'-CTGCTGGGAC-3' \\
\hline 10 & OPA-06 & 5'-GGTCCCTGAC-3' \\
\hline 11 & OPB-09 & 5'-TGGGGGACTC-3' \\
\hline
\end{tabular}




\section{MInstitute Macrothink $_{\text {Int }}$}

The sizes of RAPD products were estimated by comparison with a $1 \mathrm{~kb}$ ladder in positions 1 and 22 of the PCR gel. Bands of similar molecular weight were scored as ' 1 ' when present or ' 0 ' when absent for all accessions studied and for all the primers assessed. Data management was performed on an IBM compatible PC with the DDAT program. In addition Excel (Microsoft) and NTSYS programs (Rohlf, 1989) were used for data processing and analysis. Genetic distances between two or more genotypes were defined as quotient between un-matches and the sum of matches and un-matches. This coefficient of association measures dissimilarities and corresponds to the complement (1-SC) of the Jaccard coefficient (SC) (Goodman, 1973). Cluster analysis was performed based on these dissimilarity coefficients, using UPGMA program as a clustering method.

A cophenetic matrix was computed from the obtained tree matrix and compared with the original dissimilarity matrix in order to measure the goodness of fit (Rohlf, 1989).

Social and demographic indicators from patients were evaluated using standard structured questionnaire. The study was ethically approved by the College Research and Publications Committee of the Muhimbili University College of Health Sciences, (MU/PGS/AEC/III/126 of November 11, 1997)

\section{Results}

A total of 3000 women with VC, aged between 13 and 50, were enrolled during the study period. The social and demographic characteristics of the study sample are presented in Table 2.

Table 2. Social and demographic indicators for women with VC which contribute to Candida spp. Diversity in Dar es Salaam. Tanzania $(n=3000)$

\begin{tabular}{|lll|lr|}
\hline Variable & & N & \% \\
\hline Age group: & 1. $\quad<20$ & 512 & 17.07 \\
& 2. & $21-30$ & 1268 & 42.27 \\
& 3. $\quad 31-40$ & 1076 & 35.87 \\
& 4. & $41+$ & 144 & 4.80 \\
\hline Educational level: 1 1. No formal education & 280 & 9.33 \\
& 2. Primary & 2142 & 71.40 \\
& 3. Secondary + & 578 & 19.27 \\
\hline Occupation: & 1. Not employed & 1120 & 37.33 \\
& 2. Entrepreneurs & 1479 & 49.30 \\
& 3. Employed & 401 & 13.37 \\
\hline N. of sex partners:1. $\leq 1$ & 250 & 8.33 \\
& 2. 2-3 & 1366 & 45.53 \\
& 3. $4+$ & 1384 & 46.13 \\
\hline Marital status: & 1. Single & 550 & 18.33 \\
& 2. Married/cohabiting & 1870 & 62.33 \\
& 3. Widow/separated & 580 & 19.33 \\
\hline Pregnancy status: & 1. Not pregnant & 952 & 31.73 \\
\hline
\end{tabular}




\begin{tabular}{|c|c|c|c|}
\hline & 2. Pregnant & 2048 & 68.27 \\
\hline \multicolumn{2}{|c|}{ Prior antibiotic use: 1 . Not used } & 1054 & 35.13 \\
\hline \multicolumn{2}{|c|}{ 2. Used } & 1946 & 64.87 \\
\hline \multirow[t]{2}{*}{ Income (TShs): } & 1. $<50000$ & 2360 & 78.67 \\
\hline & 2. $50000+$ & 640 & 21.33 \\
\hline \multicolumn{2}{|c|}{ Age at first sex (years): $1 .<20$} & 2012 & 67.07 \\
\hline \multicolumn{2}{|c|}{ 2. $20-24$} & 851 & 28.37 \\
\hline & $3.25+$ & 137 & 4.57 \\
\hline \multirow{3}{*}{ HIV infection: } & 1. HIV negative & 960 & 32.00 \\
\hline & 2. HIV positive & 1826 & 60.87 \\
\hline & 3. Not tested for HIV & 214 & 7.13 \\
\hline
\end{tabular}

Almost all women were Africans aged between 21 and 40 years were 78.14\%. These participants were mainly married or cohabiting, had more than one sexual partners and an income of less than 75,000/- Tanzanian shillings ( 50 USD) per month, and had first sexual intercourse before 20 years of age.

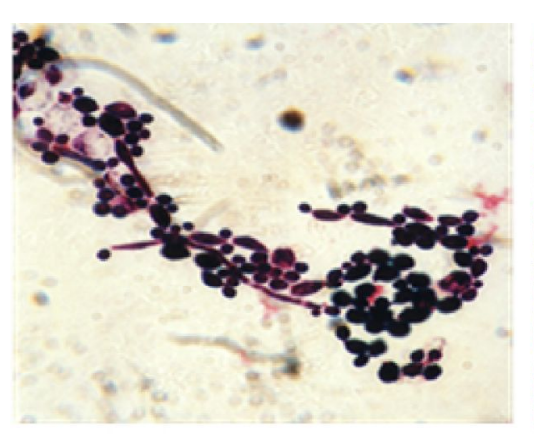

a
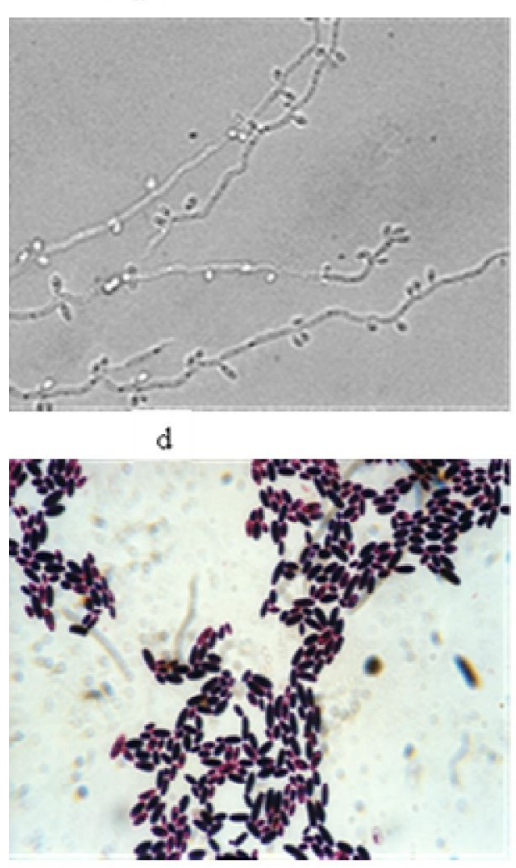

$g$
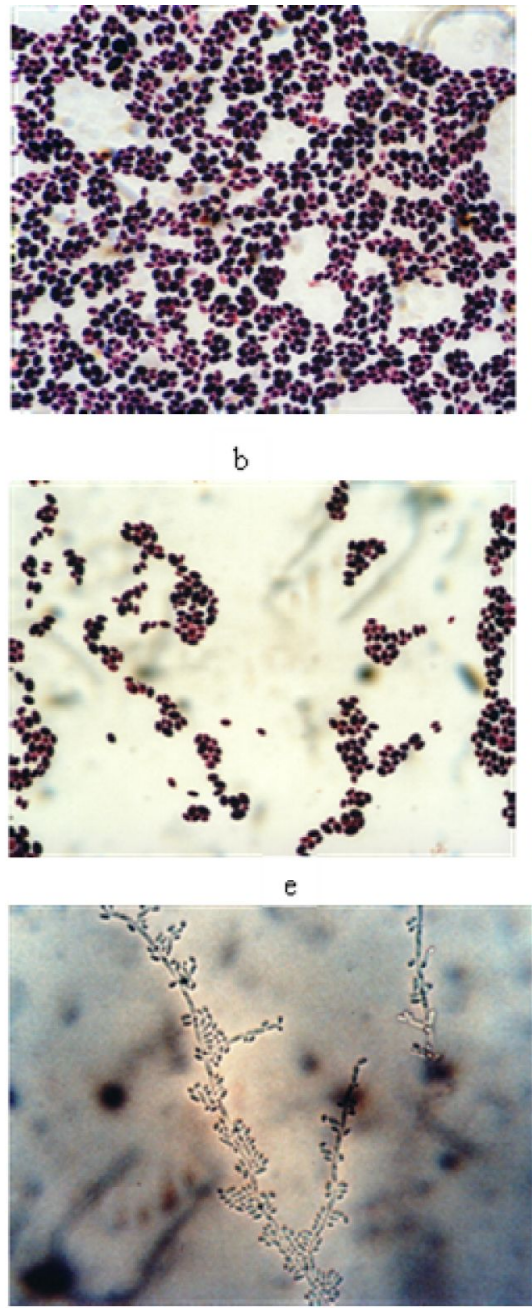

h

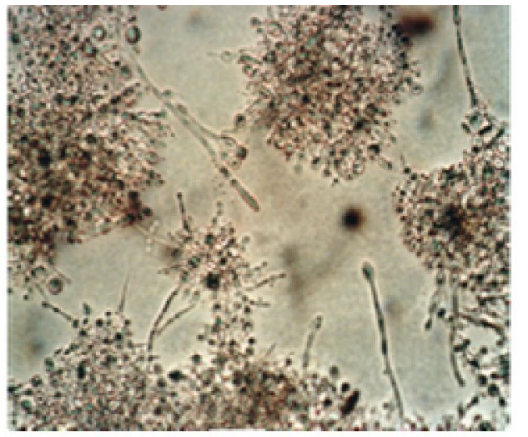

c
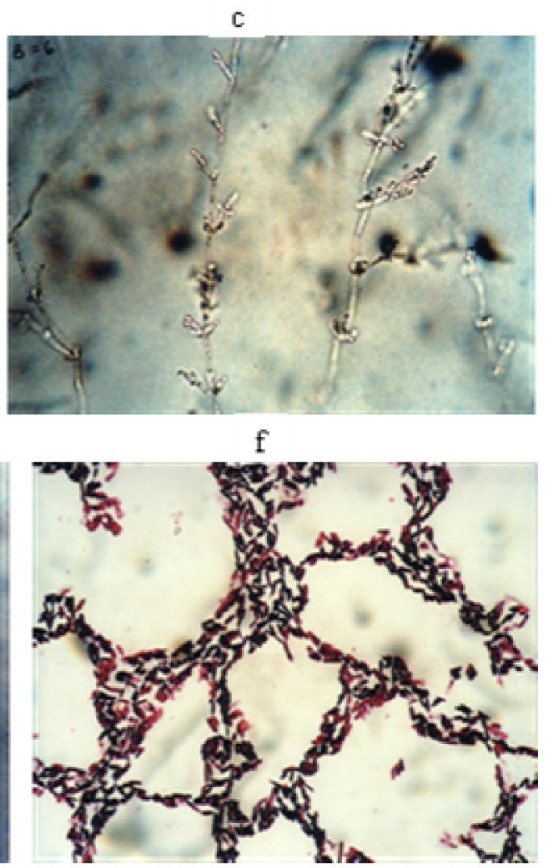

i 


\section{Ml Macrothink}

Journal of Biology and Life Science ISSN 2157-6076 2013, Vol. 4, No. 1

Figure 1. Morphological feature of different Candida species (a) Gram stained fresh patient's specimen with mixed Candida species, bacteria and some epithelial cells on SDA; (b) C. albicans from SDA gram stained; (c) Mycelial form of C. albicans on com meal agar; (d) Mycelial form of $C$. tropicalis on corn meal agar; (e) Gram stained C. glabrata on SDA; (f) Mycelial form of $C$. norvegensis on corn meal agar; (g) C. norvegensis gram stained on SDA; (h) C. krusei on corn meal agar; (i) C. krusei gram stained on SDA. (all at x400)

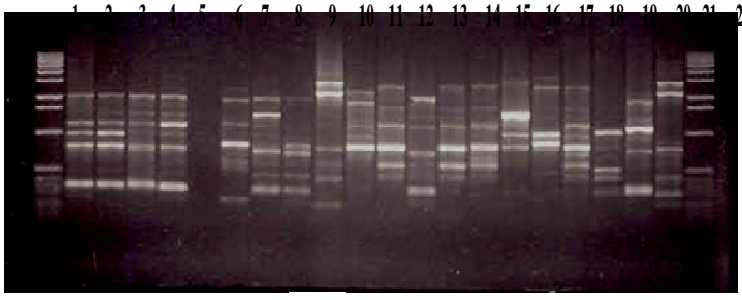

a

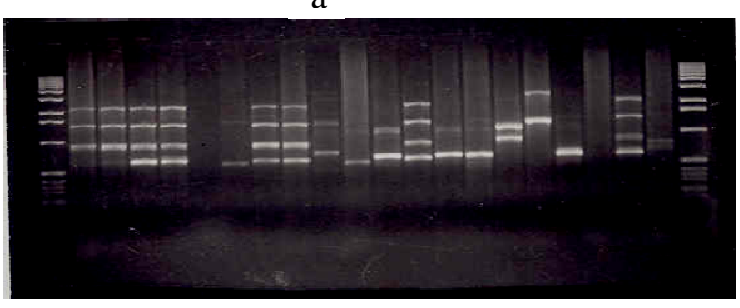

$\mathrm{c}$

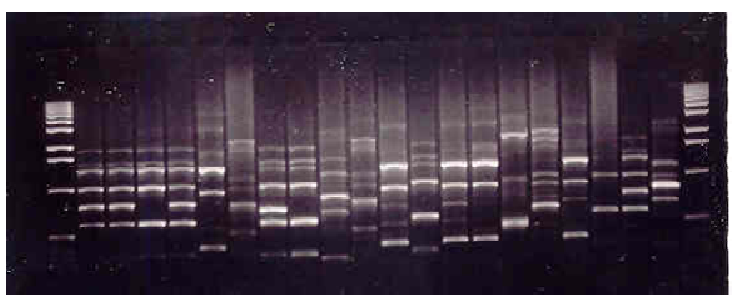

e

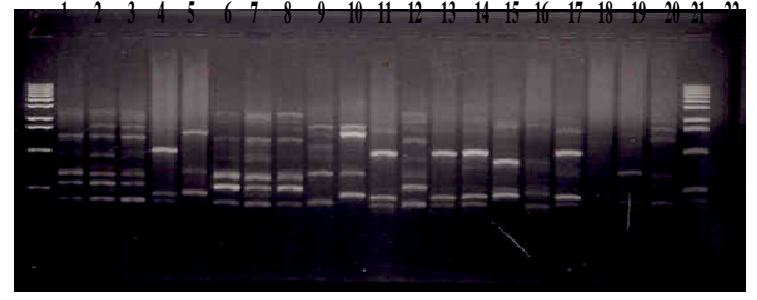

b

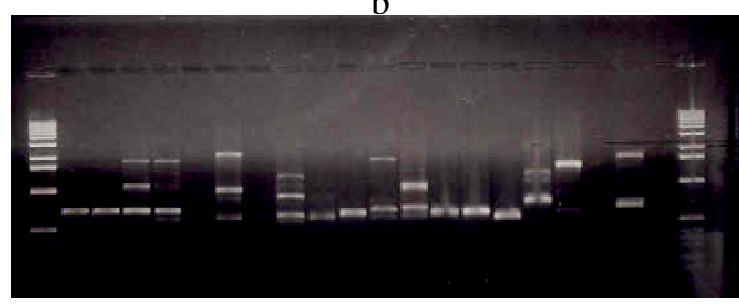

$\mathrm{d}$

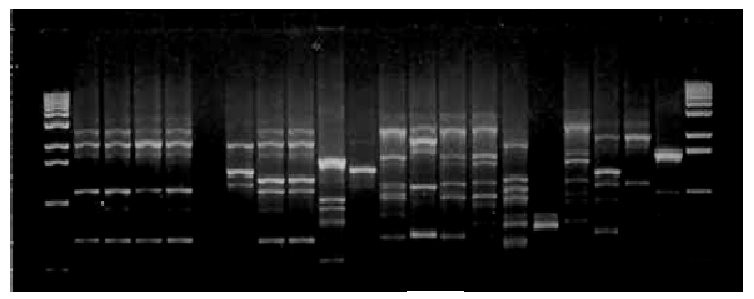

$\mathrm{f}$

Figure 2. Some RAPD profiles of Candida species (from patients) using eleven different primers from visualized on 1.0\% agarose gel; bands labeled 1-22 from left to right

Primers used in 1(a) OPA-08, in (b) OPAW-15, in (C) OPA-06, in (d) OPAX-20, (e) OPB-16, and (f) OPB-07. Arrangements from left to right is the same for all the gels; From left lane 1and 22 is $1 \mathrm{~kb}$ ladder size marker, lane2 $=C$. albicans ATCC 32354, C. albicans isolated from asymptomatic patients (lanes 3-5), and C. albicans isolated from symptomatic patients (lanes 8 , 9,13, 19 and 20), C. famata (lane6), C. glabrata (lane 12, 14, 15 and 18), C. krusei (lane 10 and 21), C. tropicalis (lane 7 and 11), C. parapsilosis (lane 17) and C. lusitaniae (lane 16).

Majority of women 1826 (60.87\%) were HIV positive (Table2), with recurrences. They visited clinic with the same complaints more than four times a year. Laboratory results of this study showed that, out of 3000 specimens cultured from 3000 women with complaints of vaginal discharges and pruritis vulvae, 5440 Candida species were isolated by growth characteristics on Sabouraud's dextrose agar and on Corn meal agar. 
Table 3. Comparison of results obtained by API Candida, API 20C AUX and PCR

\begin{tabular}{|c|c|c|c|c|}
\hline $\begin{array}{l}\text { Isolate } \quad \# / \text { or } \\
\text { Amt. }\end{array}$ & $\begin{array}{l}\text { Germ } \\
\text { tube } \\
2 \mathrm{hrs} \\
3 \mathrm{hrs} \uparrow\end{array}$ & API Candida & API 20C AUX & RAPD RESULTS \\
\hline STD HG392 & $\begin{array}{l}+ \\
+\end{array}$ & C. albicans & C. albicans 1 by $98 \%$ & C. albicans \\
\hline STDATCC32354 & $\begin{array}{l}+ \\
+\end{array}$ & C. albicans & C. albicans 1 by $99.9 \%$ & C. albicans \\
\hline 854 & $\begin{array}{l}+ \\
+\end{array}$ & C. albicans & C. albicans $1 \cong$ ATCC 32354 for 50 tested & $\begin{array}{l}\text { C. albicans } \cong \mathrm{ATCC} \\
32354 \text { for } 10 \text { tested }\end{array}$ \\
\hline 527 & $\begin{array}{l}- \\
+\end{array}$ & C. albicans & C. albicans 2 by $99.9 \%$ for 50 tested & $\begin{array}{l}\text { C.albicans for } 10 \\
\text { tested }\end{array}$ \\
\hline 448 & $\begin{array}{l}+ \\
+\end{array}$ & C. albicans & C. albicans $\cong S T D ~ H G 392$ for 50 tested & $\begin{array}{l}\text { C. albicans } \cong S T D ~ H G 392 \\
\text { for } 10 \text { tested }\end{array}$ \\
\hline 109 & - & C. famata & C. famata by $99.9 \%$ for 20 tested & $\begin{array}{l}\text { C. famata for } 10 \\
\text { tested }\end{array}$ \\
\hline 716 & $\begin{array}{l}- \\
+\end{array}$ & C. tropicalis & C. trop.(89.4)/ C.lusitan (11\%) for 50 tested & $\begin{array}{l}\text { C. } \text { tropicalis } \cong \mathrm{N} .46 \text { for } \\
5 \text { tested }\end{array}$ \\
\hline 113 & $\begin{array}{l}+ \\
+\end{array}$ & C. albicans & C.albicans $2 /$ C tropicalis for 20 tested & $\begin{array}{l}\text { C. albicans for } 10 \\
\text { tested }\end{array}$ \\
\hline 164 & $\begin{array}{l}- \\
+\end{array}$ & C. albicans & C. alb $1(69 \%) /$ C. $\operatorname{trop}(30 \%)$ for 20 tested & $\begin{array}{l}\text { C. } \text { albicans } \cong \mathrm{N} .40 \text { for } \\
10 \text { tested }\end{array}$ \\
\hline 157 & $\begin{array}{l}+ \\
+\end{array}$ & C. albicans & C. alb $1(98 \%) /$ C. $\operatorname{trop}(30 \%)$ for 20 tested & $\begin{array}{l}\text { C. } \text { albicans } \cong \mathrm{N} .40 \text { for } \\
10 \text { tested }\end{array}$ \\
\hline 327 & $\begin{array}{l}+ \\
+\end{array}$ & Trichosporon & C. albicans $2(99.5 \%)$ for 50 tested & $\begin{array}{lll}\text { C.albicans for } 10 \\
\text { tested }\end{array}$ \\
\hline 14 & - & C. magnoliae & C. magnolia for 10 tested & $\begin{array}{l}\text { C. magnoliae for } 5 \\
\text { tested }\end{array}$ \\
\hline 130 & - & C. glabrata & C. glabrata $(99.4 \%)$ for 10 tested & $\begin{array}{l}\text { C.glabrata for } 10 \\
\text { tested }\end{array}$ \\
\hline 16 & - & C. calliculosa & C. calliculosa & $\begin{array}{l}\text { C. calliculosa for } 5 \\
\text { tested }\end{array}$ \\
\hline 27 & $\begin{array}{l}- \\
+\end{array}$ & C. lusitaniae & C.lusitaniae $(60 \%)$ for 10 tested & $\begin{array}{l}\text { C. lusitaniae for } 10 \\
\text { tested }\end{array}$ \\
\hline 131 & - & C. parapsilosis & C. parapsilosis for 10 tested & $\begin{array}{l}\text { C. parapsilosis } \cong N 212 \\
\text { for } 10 \text { tested }\end{array}$ \\
\hline 452 & $\begin{array}{l}+ \\
+ \\
\end{array}$ & C. albicans & C. albicans_for 10 tested & $\begin{array}{l}\text { C.albicans for } 10 \\
\text { tested }\end{array}$ \\
\hline 290 & $\begin{array}{l}+ \\
+\end{array}$ & C. albicans & C.alb1(80) for 10 tested & $\begin{array}{l}\text { C. } \text { albicans } \cong N 14 \text { for } \\
5 \text { tested }\end{array}$ \\
\hline
\end{tabular}




\begin{tabular}{|c|c|c|c|c|}
\hline 50 & - & C. krusei & - & $\begin{array}{l}\text { C. } \text { krusei } \cong N 51 \text { for } 10 \\
\text { tested }\end{array}$ \\
\hline 46 & $\begin{array}{l}- \\
+ \\
\end{array}$ & C. albicans & C. tropicalis for 25 tested & $\begin{array}{l}\text { C. } \text { tropicalis } \cong N 12 \text { for } \\
5 \text { tested }\end{array}$ \\
\hline 13 & - & C. inconspicua & C. incospicua for 5 tested & $\begin{array}{l}\text { C. incospicua for } 10 \\
\text { tested }\end{array}$ \\
\hline 47 & - & C. krusei & $\begin{array}{l}\text { C. krusei/ C. inconsp./ Geotrichum spp. } \\
\text { for } 5 \text { tested }\end{array}$ & $\begin{array}{l}\text { C. krusei } \cong N 45 \text { for } 10 \\
\text { tested }\end{array}$ \\
\hline 159 & - & C. glabrata & $\begin{array}{l}\text { C. } \text { glabrata }(99.4 \%) \cong \text { ATCC } 2001 \text { for } 25 \\
\text { tested }\end{array}$ & $\begin{array}{l}\text { C. } \text { glabrata } \cong \text { ATCC } \\
2001 \text { for } 10 \text { tested }\end{array}$ \\
\hline 60 & $\begin{array}{l}- \\
+\end{array}$ & $\begin{array}{l}\text { C.albicans } / C \text {. } \\
\text { tropicalis }\end{array}$ & $\begin{array}{l}\text { C.collic(54)/C.magnol(45)/C.trop(30) for } 5 \\
\text { tested }\end{array}$ & C. albicans for 5 tested \\
\hline 31 & - & C. glabrata & C. glabrata $(99.4 \%)$ for 5 tested & $\begin{array}{l}\text { C. } \text { glabrata } \cong N 136 \text { for } 5 \\
\text { tested }\end{array}$ \\
\hline 89 & $\begin{array}{l}- \\
+\end{array}$ & $\begin{array}{l}\text { C. albicans/C. } \\
\text { tropicalis }\end{array}$ & C.magnol(45)/C.trop $(60)$ for 10 tested & C. albicans for 5 tested \\
\hline 20 & $\begin{array}{l}+ \\
+ \\
\end{array}$ & C. albicans & $\begin{array}{l}\text { C.alb1(80.9)/C.alb2(13)/C.tropicalis(5) for } \\
5 \text { tested }\end{array}$ & C. albicans for 5 tested \\
\hline 5 & - & C. glabrata & - & C. glabrata $\neq$ similarity \\
\hline 27 & - & C. guilliermondii & C. guilliermondii for 5 tested & $\begin{array}{l}\text { C. } \text { guilliermondii } \cong \mathrm{ATCC} \\
6260 \text { for } 10 \text { tested }\end{array}$ \\
\hline 110 & - & C. glabrata & C. glabrata $(91.5 \%)$ for 5 tested & C.glabrata for 10 tested \\
\hline 11 & $\begin{array}{l}+ \\
+ \\
\end{array}$ & C. albicans & C. alb1(98)/C. $\operatorname{trop}(30)$ for 5 tested & C.albicans for 5 tested \\
\hline 74 & - & C. norvegensis & C. norvegensis for 10 tested & $\begin{array}{l}\text { C. norvegensis for } 10 \\
\text { tested }\end{array}$ \\
\hline 3 & $\begin{array}{l}- \\
+\end{array}$ & C. norvegensis & C. norvegensis/Kloeckera spp for 3 tested & C. norvegensis for 3 tested \\
\hline 66 & - & C. krusei & C. krusei/C. inconspicua for 5 tested & C. krusei for 5 tested \\
\hline 17 & $\begin{array}{l}+ \\
+ \\
\end{array}$ & C. albicans & C. alb2/C. trop for 5 tested & C. albicans for 5 tested \\
\hline 5 & - & $\begin{array}{l}\text { C. norvegensis/ } C \text {. } \\
\text { parapsilosis }\end{array}$ & $\begin{array}{l}\text { C. norveg(45)/C. paraps(30)/C. krusei for } 5 \\
\text { tested }\end{array}$ & $\begin{array}{l}\text { C. norvegensis for all } 5 \\
\text { tested }\end{array}$ \\
\hline 22 & $\begin{array}{l}+ \\
+\end{array}$ & $\begin{array}{l}\text { C. } \quad \text { albicans/C. } \\
\text { parapsilosis }\end{array}$ & $\begin{array}{l}\text { C. parapsilosis/ C. norvegensis for } 5 \\
\text { tested }\end{array}$ & C. albicans for 3 tested \\
\hline
\end{tabular}

The species identified using diverse methods were as follows; Germ tube test show that 3661 (67.29\%) were Candida albicans. However, a considerable percentage 1779 (32.71\%) was non-albicans Candida species, mainly C. glabrata 435(8.0\%), C. tropicalis 762(14.0\%), C. 
krusei 163(3.0\%), C. famata 109(2.0\%), C. parapsilosis 131(2.41\%), C. guilliermondii and C. lusitaniae each $27(0.5 \%)$ respectively, C. incospicua $13(0.24 \%) \mathrm{C}$. norvegensis 82(1.5\%), C. colliculosa $16(0.3 \%)$ and C. magnoliae $14(0.26 \%)$ (Table3).

Table 4. Identification of Candida isolated from women with VC using API-Candida ( $\mathrm{n}=5440)$

\begin{tabular}{|c|c|c|c|c|c|c|c|c|c|c|c|c|c|}
\hline \multicolumn{12}{|c|}{ Activity In Cupule } & \multirow[t]{2}{*}{ Species } & \multirow[t]{2}{*}{ No. $(\%)$} \\
\hline Glu & Gal & $\mathrm{Sac}$ & Tre & Raf & $\begin{array}{l}\beta \\
\mathrm{Mal}\end{array}$ & $\begin{array}{l}\alpha \\
\text { Amy }\end{array}$ & $\begin{array}{l}\beta \\
\text { Xyl }\end{array}$ & $\begin{array}{l}\beta \\
\text { Gur }\end{array}$ & Ure & $\begin{array}{l}\beta \\
\text { Nag }\end{array}$ & $\begin{array}{l}\beta \\
\text { Gal }\end{array}$ & & \\
\hline+ & - & - & - & - & - & - & - & - & - & - & - & C. krusei & $163(3)$ \\
\hline+ & - & - & + & - & - & - & - & - & - & - & - & C. glabrata & $435(8)$ \\
\hline+ & - & - & - & - & + & + & - & - & - & + & - & Trichosporon & $317(5.8)$ \\
\hline+ & + & - & - & - & - & - & - & - & - & - & - & C.krusei/C.parapsilosis & $90(1.7)$ \\
\hline+ & + & - & - & - & + & + & - & - & - & + & - & Trichosporon & $10(0.18)$ \\
\hline+ & - & + & + & - & - & - & - & - & - & - & - & C. famata & $11(0.2)$ \\
\hline+ & - & + & + & + & - & - & - & - & - & - & - & C. famata & $50(0.9)$ \\
\hline+ & + & + & - & - & - & - & - & - & - & - & - & C. parapsilosis & $131(2.4)$ \\
\hline+ & + & + & - & - & - & + & - & - & - & - & - & C. tropicalis & $120(2.2)$ \\
\hline+ & + & + & - & - & - & + & - & - & - & + & - & C. albicans & $830(15.3)$ \\
\hline+ & + & + & + & - & - & + & - & - & - & - & - & C.tropicalis/C. albicans & $76(1.4)$ \\
\hline+ & + & + & + & - & - & + & - & - & - & + & - & C. albicans & $1878(34.5)$ \\
\hline+ & + & + & + & - & - & - & + & - & - & - & - & $\begin{array}{l}C \text { lusitaniae / C. } \\
\text { famata/C. tropicalis/C. } \\
\text { guilliermondii }\end{array}$ & $325(5.97)$ \\
\hline+ & + & + & + & + & - & + & - & - & - & + & - & C. albicans & $189(3.37)$ \\
\hline+ & + & + & + & - & + & + & - & - & - & - & - & C. tropicalis & $186(3.4)$ \\
\hline+ & + & + & + & - & + & + & - & - & - & + & - & C. albicans & $764(14)$ \\
\hline+ & + & + & + & - & + & - & + & - & - & - & - & C. lusitaniae & $20(0.36)$ \\
\hline+ & + & + & + & - & + & + & + & - & - & - & - & C. tropicalis & $332(6.1)$ \\
\hline
\end{tabular}


All doubtful isolates were further tested with API 20C and on API 20C AUX (Table 3). The results showed Candida albicans species to be dominant 3661 isolates while non-albicans Candida species species presented only 1779 isolates which included mixed species of $C$. glabrata, C. tropicalis, C. krusei, C. famata, C. parapsilosis, C. guilliermondii and $C$. lusitaniae , C. incospicua, C. norvegensis, C. colliculosa and C. magnoliae.

On genotypic diversity, the Polymerase chain reaction results analysed by the principle coordinate, showed the genetic relatedness and genetic distances (Figure 3) which found all the isolates distributed in 20 groups out of 200 isolates tested

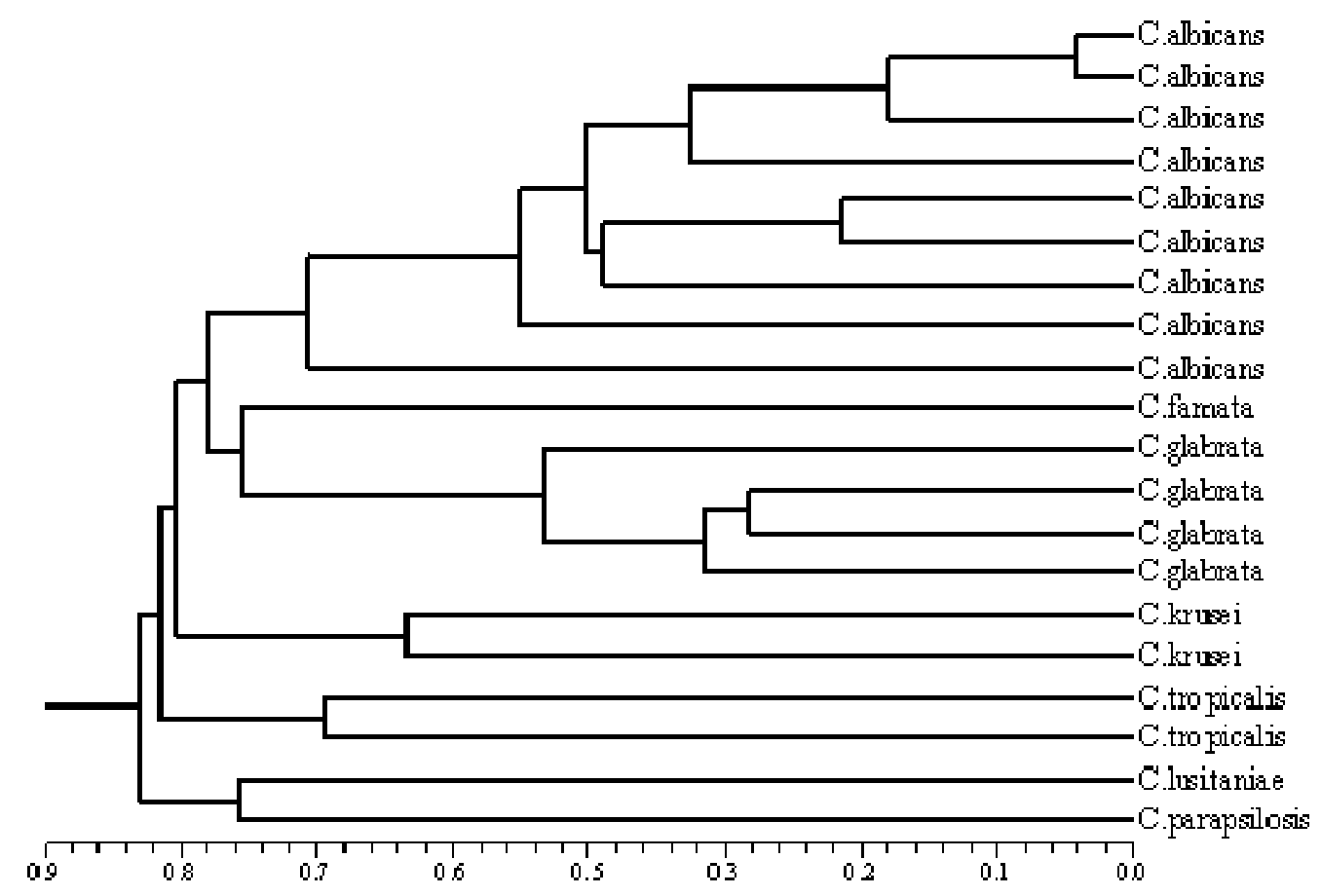

Figure 3. Phylogenetic analysis tree showing genetic relationships between the 20 Candida species, constructed using RAPD profiles of 11 primers in fig. 2.

\section{Discussion}

This study comprehensively investigated Candida species occurring in women with vaginal candidiasis who were attending HIV and gynecological clinics in Private and Government hospitals of Dar Es Salaam Region, Tanzania. The study was based on several parameters, including Analytical Profile Index (API), colonial morphology on Sabouraud's dextrose agar and corn meal agar and RAPD PCR fingerprinting. On API 20C test, the predominant types of Candida isolated were $C$ albicans 3121 (57.4\%), C tropicalis 716 (13.2\%), C glabrata 435 (8\%), C krusei 163 (3\%), C. famata 109 (2\%), C. parapsilosis 131 (2.4), C. lusitaniae 27 (0.5), and C. guilliermondii 27 (0.5\%), C. norvegensis 77(1.4\%) together making a total of $88.4 \%$ of all isolates. This finding concur with that of Okonofua and Ako-Nai (1995); Okungbowa (2002); Okungbowa et al. (2003); Kam \& Xu (2002) who also noted similar distribution of C.albicans being more abundant than other species. The other uncommon species (Table 3) accounted for less than $0.5 \%$ were $C$. magnoliae $14(0.26 \%)$ and $C$. inconspicua $13(0.23 \%)$. C. 
glabrata never showed any changed on conidia enhancing media such as Corn meal agar.

In some cases, identification with the API Candida failed to discriminate between species and lor genera; e.g. C. albicans and C. tropicalis $\mathrm{n}=2$ (Table $3 \& 4$ ) due to lack of reactions on raffinose, $\beta$ maltosidase and $\mathrm{N}$-acetyl-beta-glucosamine cupules. However, on subsequent testing the isolates were found to be germ tube positive and also formed chlamydospores on corn meal agar, features that are consistent with $C$. albicans. The difficulty in differentiating $C$. krusei from C. parapsilosis was due to variation in the assimilation of galactose and saccahrose (Table 3). The API Candida kit also had problems in differentiating some strains of $C$. lusitaniae, C. famata, C. norvogensis and C. guilliermondii due to variations of B-maltosidase and raffinose reactivity, which are the key tests for their discrimination.

It is worthy mentioning that $C$. albicans had four API profiles due to variations in the assimilation of trehalose, raffinose and B-maltosidase. $C$. famata had two API profiles due to variability in the assimilation of raffinose. The four isolates that were identified by API Candida as Trichosporon, had germ tube reaction and colonial morphological features on SDA, gram stain appearance and colonial morphology on corn meal agar that were consistent with $C$. albicans. This misidentification was attributed to the variability in assimilation of galactose, trehalose and $B$-maltosidase.

There were five disagreements between API Candida and API 20C AUX, two of them did not meet the API 20C AUX identification criteria (\% ID < 80\%). The three remaining discrepancies were: Trichosporon (API Candida) versus C. albicans (API 20C AUX), this was further tested with a germ tube test and production of chlamydospores on corn meal agar, the results confirmed to be $C$. albicans with PCR test. The second was $C$. albicans (API Candida) Vs $C$ norvegensis (API 20C AUX), while the third C. albicans (API Candida) and C. parapsilosis (API 20C AUX), these isolates were later confirmed to be $C$. albicans by PCR test (Figure 3).

The observed difficulties of the API Candida and API 20 C AUX. kits in identifying germ tube negative rare isolates such as; $C$. lusitaniae, $C$. krusei, C. parapsilosis, $C$. inconspicua and $C$. norvegensis is in keeping with the findings of other studies (Verweji, 1999; Michel-Nguyen, 2000). These findings do indicate the need to expand the battery of reagents in both kits and possibly a change of testing algorithm for adequate identification of the rare germ tube negative species. Culturing germ tube negative isolates on Corn meal agar had produced features that aided speciation (Figures 1).

The genotypic identification of species by randomly amplified polymorphic DNA from crude single-colony lysates (Steffan et al., 1997) produced simple diagnostic fingerprints that are unique to isolates of Candida species. However, few isolates of C. lusitaniae or C. norvegensis and $C$. parapsilosis could not be adequately separated, see the phylogenetic tree as one cluster (Figure 3), this limitation may be solved by using more specific primers.

The species Candida albicans, considered as one of the most pathogenic, is the most frequently isolated yeast from the vagina of both symptomatic and asymptomatic individuals. However, $C$. albicans shows various mechanisms that are suggestive of virulence such as: capacity to take on various colonial forms, called adaptive variations; ability to form hyphae (germ tube 
formation and pseudohyphae); capacity to adhere to mucosal surfaces; produces hydrolytic enzymes; proteinases which hydrolyze peptides and phospholipases which hydrolyze phospholipids .

The findings in this study also indicate that, most of the patients were young, aged below 40 years (Table 2), with only primary education and having no employment/ or entrepreneurs and had first sexual intercourse before 20 years of age. Most are co-habitors /or married but with more than one partners. This combination of factors makes these women fall in the high risk group for HIV and other sexual transmitted infections. C. albicans in this study was observed to occur in almost all age groups, indicating that $C$. albicans is a resident flora in the vagina of every woman, and this is in keeping with the study done by Tanimowo et al., (2012), Okungbowa et al., (2003).

The yeast microflora isolated from symptomatic women and those from asymptomatic women had similar species and genotypic diversities (Xu et al., 1999, Boldo et al., 2003). However, it was noted from symptomatic women that, a single host can be colonized with multiple species or multiple genotypes of the same species, a trend that is in keeping with other studies Xu et al., (1999), Kam \& Xu (2002).

Among 1826 women with HIV infection in this study; 1713 (93.81\%), were found to have recurrent vaginal candidiasis and were carrying species that are resistant to treatment especially with azoles. Several reasons might be the cause, for this trend to have refractory and recurrence vaginal candidiasis, including; increased incidences of vaginal candidiasis associated with non-albicans Candida species such as C. glabrata, C. krusei, C. tropicalis, C. lusitaniae etc, because 1672(93.98\%) non-albicans Candida species from 1779 were isolated from HIV patients with recurrent vaginal candidiasis. This result is in keeping with studies done by; Hazen (1995), Sobel (1998), Sheehan et al., (1999), Abu-El-teen, (2001), Erika (2000).

Majority of HIV patients in Tanzania are given Fluconazole tablets for prophylaxis of vaginal thrush and cryptococcal meningitis, the compliance to therapy in such patients is not known, there might be uncontrolled consumption of antifungal preparations, which may have been resulted in secondary, resistance, i. e. increasing usage of short course antifungal therapies, inadequate treatment or poor patients compliance e.g. drug interruptions in patients with recurrent vaginal candidiasis had enabled the emergence of less common more resistant yeast strains as vaginal pathogens, this is in keeping with studies done elsewhere, (Jovanovic et al., 1991, Bjornson et al., 1992, Rex et al., 1995, Silverman et al., 2001, Segal \& Minamoto, 2001).

Although this study revealed interesting results, it yet had some limitations. For instance the methods used to identify a large number of isolates were not discriminatory (Table $3 \& 4$ ) especially the API- identification results gave more than one species, only the PCR method was discriminatory, but due to financial constraints it was not possible to study species characteristics in a large sample size. This study therefore recommends further studies using molecular methods with specific primers that will discriminate candida species, also to study specific underlying factors in order to compare Candida species carriage in healthy individuals with that of patients. There is also a need to study the pathogenicity factors associated with 
Candida species in order to find out, as to why the same species behave differently from asymptomatic to symptomatic persons.

\section{Conclusion}

In conclusion, the findings of this study do show that approximately half of women seeking primary health care for vaginal discharge and pruritis vulvae have $\mathrm{VC}$, and also, a larger percentage $(93.98 \%)$ of HIV patients are carrying non-albicans Candida species which are resistant to treatment leading to recurrences. This finding should be taken into account when considering management of women with vaginal discharge or pruritus vulvae. The results of this study also indicate that a combination of biochemical methods and RAPD technology are feasible for identification and differentiation of various pathogenic Candida isolates, including the germ tube negative isolates. The results also revealed that a single host with symptoms of vaginal candidiasis can harbor multiple Candida species (fig. 1a). Moreover, the significance of increased species diversity in vaginal Candida carriage must be investigated in relation to the development of candidiasis.

\section{Acknowledgement}

The author is thankful to the Nijmigen University through Netherlands Universities Foundation for International Cooperation (NUFFIC) who partly sponsored sample collection. The author is also indebted to Lab Scientists UDSM-Molecular biology and biotechnology department, at Muhimbili University of Healthy and allied Sciences, and at Mikocheni Agricultural Research Institute who helped with sample analysis and to all the volunteers for contributing to the sample collection.

\section{References}

Abu-Elteen KH. (2001). Increased incidence of vulvo Vaginal Candidiasis caused Candida glabrata in Jordan. Japanese J. Infect. Dis. 54, 103-107.

Baeten, J. M, Nyange, P. M, Richardson, B. A, et al., (2001). Hormonal contraception and risk of sexually transmitted disease acquisition: results from a prospective study. Am. J. Obstet. Gynecol. 185, 380-385. http://dx.doi.org/10.1067/mob.2001.115862

Barhan, S. \& Ezenagu, L. (1997). Vulvar problems in elderly women. Don't assume that menopause is the culprit. Postgrad. Med. 102, 121-125, 131-132. http://dx.doi.org/10.3810/pgm.1997.09.312

Boldo XM, Villa-Tanaca L, Zuniga G, Hernandez-Rodriguez U. (2003). Genetic Diversity among Clinical Isolates of Candida glabrata Analyzed by Randomly Amplified Polymorphic DNA and Multilocus Enzyme Electrophoresis Analyses. J Clin Microbiol, 41(10), 4799-4804. http://dx.doi.org/10.1128/JCM.41.10.4799-4804.2003

Chaim W, Foxman B \& Sobel JD. (1997). Association of recurrent VC and secretory ABO and Lewis phenotype. J. Infect. Dis. 176, 828-830. http://dx.doi.org/10.1086/517314

Cassone A, De Bernardis F, Pontieri E, Carruba G, Girmenia C, Martino P, Fernández-Rodríguez M, Quindós G \& Pontón J. (1995). Biotype Diversity of Candida 
parapsilosis and Its Relationship to the Clinical Source and Experimental Pathogenicity. The Journal of Infectious Diseases, 171, 4,967-975. http://dx.doi.org/10.1093/infdis/171.4.967

Chong PP, Lee YL, Tan BC \& Kee Peng Ng. (2003). Genetic relatedness of Candida strains isolated from women with vaginal candidiasis in Malasya. J. Med Microbiol. 52, 657-666. http://dx.doi.org/10.1099/jmm.0.04973-0

Chu JH, Feudtner C, Heydon K, Walsh TJ \& Zaoutis TE. (2006). Hospitalizations for endemic mycoses: a population-based national study. Clin. Infect. Dis. http://dx.doi.org/10.1086/500405

Cutler JE. (1991). Putative virulence factors of Candida albicans. Ann. Rev. Microbiol. 45, 187-218. http://dx.doi.org/10.1146/annurev.mi.45.100191.001155

De Bernardis F, Adriani D, Lorenzini R, Pontieu E, Carruba G \& Cassone A. (1993). Filamentous growth and elavated vaginopathic potential of a nongerminative variant of Candida albicans expressing low virulence in systemic infection. J.Infect. Immun. 61, 1500-1508.

De Leon, E. M., Jacober, S. J., Sobel, J. D. \& Foxman, B. (2002). Prevalence and risk factors for vaginal Candida colonization in women with type 1 and type 2 diabetes. BMC. Infect. Dis., 2, 1. http://dx.doi.org/10.1186/1471-2334-2-1

Dennerstein G. (1998). Comment in: Pathogenesis and treatment of genital candidiasis. Aust. Fam. Physician. 27, 363-369.

Denning DW. (1995). Management of genital candidiasis. Brit. Med. J., 310, 1241-1244. http://dx.doi.org/10.1136/bmj.310.6989.1241

Eckert LO, Hawes SE, Stevens CE, Koutsky LA, Eschenbach DA, \& Holmes KK. (1998). Vulvovaginal candidiasis: clinical manifestations, risk factors, management algorithm. Obstet Gynecol, 92(5), 757-765. http://dx.doi.org/10.1016/S0029-7844(98)00264-6

Erika NR. (2000). Treatment of Recurrent Vulvovaginal Candidiasis. Am Fam Physician, 61(11),3306-3312.

Fidel PL, Vazquez JA, \& Sobel JD. (1999). Candida glabrata: Review of epidemiology, pathogenesis, and clinical disease with comparison to C. albicans. Clin. Microbiol. Rev. 12, $80-96$.

Fischer GO. (2001). Vulval disease in pre-pubertal girls. Australas J. Dermatol. 42, 225-234, quiz, 235-236. http://dx.doi.org/10.1046/j.1440-0960.2001.00526.x

Foxman B, Sobel JD. and Geiger AM. (1995). Chronic vulvovaginal candidiasis, characteristics of Women with Candida albicans, C. glabrata and no Candida. Genitorin. Med. 71, 304-307.

Ginter G, Soyer HP, and Rieger E. (1992). Vaginal yeast colonization and promiscuity. A study of $197 \quad$ prostitutes. Mycoses, $\quad 35, \quad$ 177-180. http://dx.doi.org/10.1111/j.1439-0507.1992.tb00841.x 
Hazen KC. (1995). New and emerging yeast pathogens. Clin. Microbiol. Rev. 8, 462-478.

Higgs JM, Wells RS. (1972). Chronic Muco-cutaneous Candidiasis: Associated Abnormalities of Iron Metabolism. BJD. 86, 88-102. http://dx.doi.org/10.1111/j.1365-2133.1972.tb15420.x

Hube B. (1996). Candida albicans secreted aspartyl proteinase. Curr. Top. Med. Mycol. 7, 55-69.

Hunter PR, Fraser CA, \& Mackenzie DW. (1989). Morphotype markers of virulence in human candidal infections. J. Med Microbiol. 28, 85-91. http://dx.doi.org/10.1099/00222615-28-2-85

Jovanovic R, Congema E, Nguyen HT. (1991). Antifungal agents vs. boric acid for treating chronic mycotic vulvovaginitis. J. Reprod Med. 36,593-7.

Kam AP \& Xu J. (2002). Diversity of commensal yeasts within and among healthy hosts. Diagn Microbiol Infect Dis. 43(1), 19-28. http://dx.doi.org/10.1016/S0732-8893(02)00364-4

Mahmoudi Rad M, Zafarghandi AS, Zabihi MA, Mahkam Tavallaee M \& Mirdamadi Y. (2012). Identification of Candida Species Associated with Vulvovaginal Candidiasis by Multiplex PCR. Infectious Diseases in Obstetrics and Gynecology. Article ID 872169, 5 pages, doi:10.1155/2012/872169.

Marin MG, King R, Sfameni S and Dennerstein GJ. (2000). Adverse behavioral and sexual factors in chronic vulvar disease. Am. J. Obstet. Gynecol. 183, 34-38.

Moraes PS. (1998). Recurrent VC and allergic rhinitis: A common association. Ann. Allergy Asthma Immunol. 81, 165-169. http://dx.doi.org/10.1016/S1081-1206(10)62804-9

Namkinga LA, Matee MIN, \& Kivaisi AK. (2005). Prevalence and risk factors for vaginal candidiasis among women seeking primary health care for genital Infections in Dar Es Salaam, Tanzania. East African Medical Journal, 82(3), 138-143. http://dx.doi.org/10.4314/eamj.v82i3.9270

Namkinga LA, Matee MIN, Kivaisi AK, Kullaya A \& Mneney EE. (2005). Identification of Candida strains isolated from Tanzanian pregnant women with vaginal candidiasis. East African Med. J. 82, 226-234.

Nasibwa A and Godfrey R. (1994). Irrational drug prescribing in developing countries. Lancet, 343, 358-359. http://dx.doi.org/10.1016/S0140-6736(94)91198-3

Nucci M, \& Marr KA. (2005). Emerging fungal diseases. Clin. Infect. Dis. 41,521-526. http://dx.doi.org/10.1086/432060

Nwokolo NC and Boag FC. (2000). Chronic VC. Management in the postmenopausal patient. Drug Aging, 16, 335-339. http://dx.doi.org/10.2165/00002512-200016050-00003

Odds FC, Abbott AB, Reed TAG and Willmott FE. (1983). Candida albicans strain types from the genitalia of patients with and without Candida infection. Eur. J. Obset, Gynecol. Rep. Biol. $15,37-43$.

Okonofua FE, Ako-Nai KA. (1995). Dighitoghi M.D. Lower genital tract infections in infertile 
Nigerian women compared with controls. Genit. Med. 71(3), 163-168.

Okungbowa FI. (2002). Biology and diversity of Candida species isolated from the human genitourinary tract in some Nigerian cities. PhD Thesis, University of Benin, Nigeria.

Okungbowa FI, Isikhuemhen OS, Dede APO. (2003). The distribution frequency of Candida species in the genitourinary tract among symptomatic individuals in Nigerian cities: Rev. Iberoam. Micol. 20, 60-63.

O’Neill S and Howard J. (1989). Recurrent vulvoVC. A gynaecological enigma. Aust. Fam. Physician. 18, 99-102.

Pfaller MA, \& Diekema DJ. (2004). Rare and emerging opportunistic fungal pathogens: concern for resistance beyond Candida albicans and Aspergillus fumigatus. J. Clin. Microbiol. 42, 4419-4431. http://dx.doi.org/10.1128/JCM.42.10.4419-4431.2004

Pfaller MA, Diekema DJ. (2007). Epidemiology of Invasive Candidiasis: a Persistent Public Health Problem. Clin. Microbiol. Rev. 20(1), 133-163. http://dx.doi.org/10.1128/CMR.00029-06

Rex JH, Rinaldi MG, Pfaller MA. (1995). Resistance of Candida species to fluconazole. Ant. Agents Chemother. 39, 1-8. http://dx.doi.org/10.1128/AAC.39.1.1

Rohlf FJ. (1989). NTSYS-PC Numerical taxonomy and multivariate analysis system. Exerter Publ. Setauket, N.Y.

Samaranayake YH, Samaranayake LP, Yau JYY, Dassanayake, RS, Li TKL and Anil S. (2003). Phenotypic diversity of oral $C$. albicans isolated on single and sequential visits in an $\begin{array}{llll}\text { HIV-infected Chinese } \quad \text { cohort. } & \text { 3PMIS, } 337 .\end{array}$ http://dx.doi.org/10.1034/j.1600-0463.2003.1110206.x

Sheehan DJ, Hitchcock CA and Sibley CM. (1999). Current and emerging azole antifungal agent agents. Clin. Microbiol. Rev. 12, 40-79.

Sobel JD, Myers P, Levisan ME and Kaye D. (1981). C. albicans adherence to vaginal epithelial cells. J. Infect. Dis. 143, 76-82. http://dx.doi.org/10.1093/infdis/143.1.76

Sobel JD. (1985). Epidemiology and pathogenesis of recurrent vulvovaginal candidiasis. Am. J. Gynecol. 152, 924-935.

Sobel JD. (1989). Pathophysiology of vulvo Vaginal Candidiasis. J. Reprod.Med. 34, 572-580

Sobel JD. (1992). Pathogenesis and treatment of recurrent vulvovaginal candidiasis. Clin. Inf. Dis. 14, 148-153. http://dx.doi.org/10.1093/clinids/14.Supplement_1.S148

Sobel JD. (1993). Candidal vulvovaginitis. Clin Obstet Gynecol. 36, 153-65. http://dx.doi.org/10.1097/00003081-199303000-00021

Sobel JD, Faro S, Force RW, Foxman B, Ledger WJ, Nyirjesy PR, et al. (1998). Vulvo Vaginal Candidiasis: epidemiologic, diagnostic and therapeutic considerations. Am. J. Obstet. Gynecol. 78, 203-211. http://dx.doi.org/10.1016/S0002-9378(98)80001-X 


\section{Macrothink}

Sobel JD. (1998). Vulvovaginitis. When Candida becomes a problem. Dermatol Clin. 16, 763-768. http://dx.doi.org/10.1016/S0733-8635(05)70043-7

Spinillo A, Pizzoli G, Colonna L, Nicola S, De Seta, F and Quaschino S. (1993). Epidemiology characteristics of women with idiopathic recurrent vulvoVC. Obstet. Gynaecol, 81, 721-727.

Steffan P, Vazquez JA, Boicov D, Xu C, Sobel, JD and Akins RA. (1997). Identification of Candida species by randomly amplified polymorphic DNA fingerprinting of colony lysates. $J$. Clin. Microbiol, 35(8), 2031-2039.

Tanimowo OW, Ogbeke AJ, Nwachukwu PU, Igborgbor JC, \& Utebor EK. (2012). The Prevalence of Vaginal Candidiasis among female students in Novena University, Delta State, Nigeria. Intern J. of Pharm Research and Dev. 4(03), 323-331.

Walsh TJ, Groll A, Hiemenz J, Flemming R, Roilides E, \& Anaissie E. (2004). Infections due to emerging and uncommon medically important fungal pathogens. Clin. Microbiol. Infect. 10(Suppl. 1), 48-66. http://dx.doi.org/10.1111/j.1470-9465.2004.00839.x

Xu J, Boyd CM, Livingston E, Meyer W, Madden JF \& Mitchell TG. (1999). Species and genotypic diversites and Similarities of pathogenic yeasts colonizing women. J. Clin Microbiol, 37, 3835-3843.

\section{Copyright Disclaimer}

Copyright reserved by the author(s).

This article is an open-access article distributed under the terms and conditions of the Creative Commons Attribution license (http://creativecommons.org/licenses/by/3.0/). 